\title{
An Assessment Of The Crash of Exchange On The Appearance Of Category With Unique Mentioning To India
}

\author{
Bhargava Chidaksh
}

Department Of History Bhu - Banaras Hindu University, India

\section{ABSTRACT}

Since most recent twenty years we have been seeing a paradigmatic shift both in principle and capacity of the state. The world has encountered a category which moves back on its capacities and obligations. It implies an adjustment of the idea of the state. This change is generally called as the retreat of the category and it has expected another job via completing the disinvestment and privatization in all stroll of its life. The new job and the capacity of the category is making great conditions for private ventures and exchange influences and chopping down the use on government assistance approaches. The rise of exchange influences over the category and its capacities has left broad ramifications on the overall category of the general public and jobs of normal masses. In this unique situation, the article will talk about how far the exchange influences have affected the exercises of the category for the sake of improvement methodology

KEYWORDS:- State, market, financial changes, order economy, exchange economy

\section{INTRODUCTION}

Throughout some undefined time frame, the category has developed as an idea and organization through changing situations and human relations. The category is considered as a characteristic affiliation and furthermore an important pre-condition for acculturated and secure life. Today, we have various originations in regards to the job, powers and elements of the state. In the advanced period, we have seen the development of country states; they have assumed a bringing together part over its populace and region. The cutting edge states have shown some measure of responsibility towards the government assistance of residents. The coming of neoliberal rule as strategy and practice has changed the nature and exercises of state. Be that as it may, the action of the category is generally assessed as far as financial improvement as opposed to government assistance measures attempted by it. In the viewpoint of the market, the intercession of the category was viewed as decidedly hurtful to the economy. This has raised the contention from the political and monetary circles for the rollback of the state. The powers of globalization have added further fillip to this sort of thought and practice. At the appointed time of time, the creating scene has changed its point of view on the category by accepting business sector cordial procedures and its job has been decreased to a moderate state. 
CURRENT RESEARCH JOURNAL OF HISTORY 2(5): 06-08, May 2021

DOI: https://doi.org/10.37547/history-crjh-02-05-02

ISSN 2767-472X

(C)2021 Master Journals

Crossref doi 8 Google

Accepted 15 $5^{\text {th }}$ May, 2021 \& Published 20 ${ }^{\text {th }}$ May, 2021

\section{Methods}

The issue with regards to agricultural nations like India is economically more basic in that there are huge parcels of destitution, low proficiency, chronic frailty framework and helpless foundation. The inquiry, nonetheless, is one of finding some kind of harmony. It is accepted that, exchange is a proficient component which can undoubtedly figure out every one of the issues faced by the economy. On account of item creation, the benefit intention may function admirably. Be that as it may, this benefit inspiration point might be laden with significant issue in territories like wellbeing, training and neediness mitigation. There could be no other option except for to have generous category activity in every one of these spaces. Category can assume a superior part in setting the heading as opposed to driving. The administrative part of the public authority in the monetary and different areas has accepted added significance with regards to financial emergency. Also, category intercessions become essential just in zones where markets don't exist or where they can't perform effectively. With restricted asset accessibility, government ought to redistribute assets more in zones where it enjoys a relative upper hand over the exchange and clear those where it has less of a benefit. Hence, the public authority can't renounce this job, despite the fact that, it is undoubtedly a troublesome one during the time spent globalization. Category needs to seek after this job more uniquely in contrast to it did before. It should figure out how to make redistributive arrangements effective and all around focused. Furthermore, it should not fail to remember that development is the best medication for restoring the sickness of total neediness and for giving profitable positions Rangarajn, 2001: 1391.

\section{Discussion}

The current world is encountering a sort of progress which represents a situation to the presence of country states. In this globalized age, the country category has become the survivor of another sort of change and challenge. This test has put stakes on the cohesiveness and authority of country category obtained by it since its introduction to the world. Also, it has the ability to rework the request for countries on the planet governmental issues. It has changed the existence of the category by making category not, at this point an expert for securing poor people and the impeded.

\section{Conclusion}

The exchange is certainly not a characteristic request as Adam Smith and different business analysts professed to be. The exchange economy is a human intercession that can't be normally mixed with public activity since it prompts the full commodification of all methods from ordinary attractive delivered wares. The augmentation of commodification to all parts of human existence prompts strain among economy and society.

\section{REFERENCES}

1. gourav shrivastav, "Was Indian Growth Story Any Different?" accessible at www.stcipd.com/UserFiles/File/Was Indian Growth Story Any Different.pd retrieved on 14/2/2014]. 
CURRENT RESEARCH JOURNAL OF HISTORY 2(5): 06-08, May 2021

DOI: https://doi.org/10.37547/history-crjh-02-05-02

ISSN 2767-472X

(C)2021 Master Journals

Crosser do) 818 Google

Accepted 15th May, 2021 \& Published 20 th May, 2021

2. Dashrath das, Bipin, 2004. Globalization: India's Adjustment Experience, New Delhi: Sage Publications: 13-284.

3. mortin disusa, 'Category versus Exchange a few contentions to outperform the "reflect approach", Available at http://www.ectap.ro/state_versus market some arguments to _surpass the mirror approach by an ca dodescu/a497/[retrieved on 6/2/2014].

4. faraz, k. and altaf, Rahat, 'The government assistance category and the Exchange Economy: Which Way Ahead', accessible at www.jgbm.org/page/348 altaf rahat.pdf [retrieved on $7 / 3 / 2015$ ].

5. A . dhangar, 'Category Intervention versus Free Market', accessible at www.jostor.org/stable/4397576 [retrieved on $25 / 02 / 2012]$.

6. A. ranatunga, 'Globalization and changing design of the express: the administrative category and the governmental issues of negative coordination', accessible at www.tandfonline.com/loi/rjpp21 [retrieved on $12 / 1 / 2012]$. 